\title{
Assembling Palladium and Cuprous Oxide Nanoclusters into Single Quantum Dots for the Electrocatalytic Oxidation of Formaldehyde, Ethanol, and Glucose
}

Jasper Biemolt, Dylan van Noordenne, Jianwen Liu, Elise Antonetti, Manon Leconte, Stefan van Vliet, Roland Bliem, Gadi Rothenberg, Xian-Zhu Fu, and Ning Yan*

Cite This: ACS Appl. Nano Mater. 2020, 3, 10176-10182

Read Online

ABSTRACT: To effectively manipulate the electronic structure of the catalysts, we present here a simple bottom-up synthesis protocol for agglomerating palladium and cuprous oxide ultrasmall nanoclusters into single nanoparticles, forming so-called quantum dot assemblies (QDAs). Our synthesis is based on the galvanic displacement of copper with palladium cations under $\mathrm{O}_{2}$-free conditions, rendering the simultaneous and unique crystal growth of $\sim 3 \mathrm{~nm} \mathrm{Cu}_{2} \mathrm{O}$ and Pd clusters. Such assemblies, comprising ultrasmall nanoconstitutes, offer much more phase boundaries, where the interfacial electronic effect becomes prominent in catalysis. This is demonstrated in the electrocatalytic oxidation of formaldehyde, ethanol, and glucose. In all three cases, the

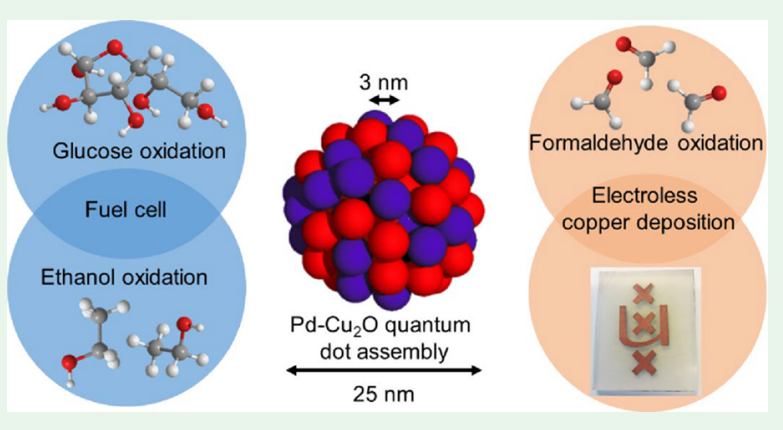
QDA catalyst, despite its similar Pd loading, outperforms the monometallic palladium catalyst. Indeed, complementing the experimental results with density functional theory calculations, we could confirm the sharply increased charge density at the $\mathrm{Pd}-\mathrm{Cu}$ heterojunction and the decreased energy barrier of the formaldehyde oxidation on the QDA catalyst. Finally, we applied these catalysts in electroless copper deposition - an industrially relevant process for manufacturing printed circuit boards. The QDA catalysts gave uniform and robust copper wires at a rate that was three times faster than that of the monometallic Pd catalyst, showing their potential for real-life applications.

KEYWORDS: electronic structure, ultrasmall nanoparticles, synergistic effect, electrocatalyst, electroless deposition

\section{INTRODUCTION}

Engineering the topology of catalysts at the nanoscale is one of the most effective approaches for optimizing their performance. It allows the construction of hybrid systems comprising different components within the same nanostructure. ${ }^{1-5}$ Such assemblies can result in the formation of optimized active sites thanks to the physical and chemical interactions of constituent components. The synergistic effect is often prominent at the interface, where the electronic and geometric interactions start affecting one another. ${ }^{6-8}$ Thus, creating more of these boundaries can be beneficial for catalysis.

Intuitively, decreasing the size of the nanoclusters in the assemblies will create more interfaces. In particular, when the clusters become small enough to be considered as quantum dots ( $\mathrm{d}<3 \mathrm{~nm}$, also called ultrasmall nanoparticles), quantum effects start influencing the catalytic properties significantly. $^{9-13}$ There are various ways for making nanoclusters. Based on the pioneering work by LaMer and Dinegar, ${ }^{14}$ monodisperse nanoclusters are produced by controlling the different colloidal growth phases. Surfactants are typically used to influence these growth phases, offering control over the particle size, shape, and crystal structure. This can yield well- defined and highly active catalysts. ${ }^{15-18}$ Alternatively, one can also use physical methods such as atomic layer deposition or vapor phase deposition. ${ }^{19,20}$ These gas-based methods give even better control over the final catalyst structure. ${ }^{21-23}$ They are excellent for lab-scale catalyst synthesis and are often used for making model catalysts for fundamental studies. However, the high cost hinders their practical application in industry.

Notwithstanding the progress in nanocluster synthesis, hybridizing multiple types of nanoclusters to form quantum dot assemblies (QDAs) remains a difficult challenge. Now, motivated by the prospect of strengthening the interfacial electronic effect in such assemblies, we show that simple galvanic displacement is an effective approach for making QDAs. In the literature, this method is often used to grow conventional nanostructures such as core-shells, dumbbells,

Received: August 9, 2020

Accepted: September 27, 2020

Published: September 27, 2020 
nanotubes, and nanospheres. ${ }^{24-27}$ Their structure dimensions are typically larger than $50 \mathrm{~nm}$. By taking advantage of the competing crystal growth of the $\mathrm{Cu}_{2} \mathrm{O}$ and $\mathrm{Pd}$, we succeeded in preventing the overgrowth of the two types of nuclei. The resulting quantum dots of $\mathrm{Cu}_{2} \mathrm{O}$ and $\mathrm{Pd}$ are both ca. $3 \mathrm{~nm}$ in diameter, agglomerating into QDAs of $10-25 \mathrm{~nm}$. Thanks to the maximized interfacial electronic effect as supported by the simulation results, our $\mathrm{Cu}_{2} \mathrm{O}-\mathrm{Pd}$ QDAs are excellent catalysts for the electro-oxidation of small organics (formaldehyde, glucose, and ethanol), outperforming even pure $\mathrm{Pd}$ nanoparticles. In the electroless copper deposition (ECD) process, which is industrially relevant for the fabrication of printed circuit boards (PCBs), ${ }^{28,29}$ the new catalysts accelerate the deposition rate three-fold, promoting the growth of robust copper wires on flexible substrates. The fact that our method uses only water as the solvent, without any additive, increases the opportunities for industrial applications.

\section{RESULTS AND DISCUSSION}

2.1. Synthetic Strategy and Materials Characterization. The geometric structure and the synthetic strategy of $\mathrm{Cu}_{2} \mathrm{O} / \mathrm{Pd} \mathrm{QDAs}$ are illustrated in Figure 1. After obtaining

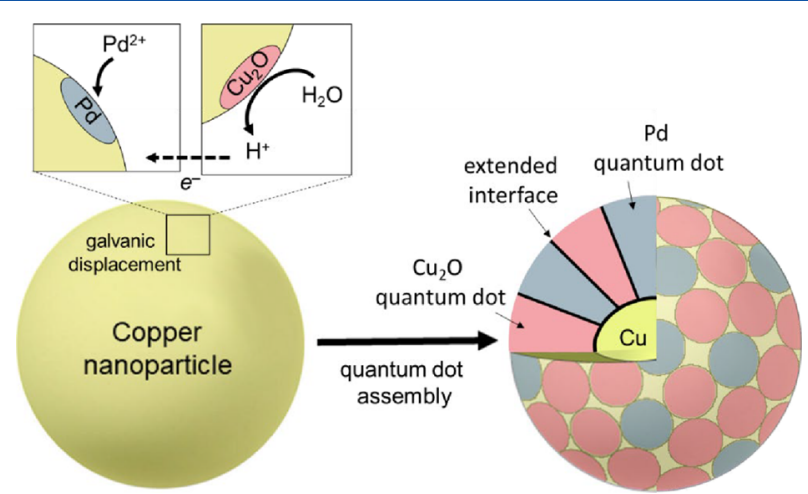

Figure 1. Schematic illustration of the growth and configuration of a $\mathrm{Pd}$ and $\mathrm{Cu}_{2} \mathrm{O}$ QDA.

the copper nanoparticles ( 8 wt \%) supported on Vulcan XC$72 \mathrm{R}$, QDAs were synthesized through the galvanic displacement reaction shown in eq 1 in the absence of $\mathrm{O}_{2}$ (see the Supporting Information for details). The redox potential difference between palladium and copper (eqs 2 and 3 ) results in copper oxidation and $\mathrm{Pd}^{2+}$ reduction. Usually, the copper atoms would be oxidized following a two-electron process all the way to soluble $\mathrm{Cu}^{2+}$ cations. In our system, however, the reaction gives insoluble $\mathrm{Cu}_{2} \mathrm{O}$ (eq 4 ) as the reaction took place in an $\mathrm{O}_{2}$-free environment. ${ }^{30}$ The palladium and the cuprous oxide particles grow simultaneously during the galvanic displacement (as illustrated in Figure 1 and eq 1). Each phase inhibits the growth of the other in its vicinity, resulting in the formation of ultrasmall nanodomains on the native $\mathrm{Cu}$ nanoparticle.

$$
\begin{aligned}
& 2 \mathrm{Cu}^{0}+2 \mathrm{OH}^{-}+\mathrm{Pd}^{2+} \rightarrow \mathrm{Cu}_{2} \mathrm{O}+\mathrm{H}_{2} \mathrm{O}+\mathrm{Pd}^{0} \\
& E_{0}=+1.275 \mathrm{~V} \\
& \mathrm{Cu}^{2+}+2 e^{-} \rightarrow \mathrm{Cu}^{0} \quad E_{0}=+0.342 \mathrm{~V} \\
& \mathrm{Pd}^{2+}+2 e^{-} \rightarrow \mathrm{Pd}^{0} \quad E_{0}=+0.915 \mathrm{~V}
\end{aligned}
$$

$$
\begin{gathered}
\mathrm{Cu}_{2} \mathrm{O}+\mathrm{H}_{2} \mathrm{O}+2 e^{-} \rightarrow 2 \mathrm{Cu}^{0}+2 \mathrm{OH}^{-} \\
E_{0}=-0.360 \mathrm{~V}
\end{gathered}
$$

We then varied the size and number of the nanoclusters in the $\mathrm{Pd}-\mathrm{Cu}_{2} \mathrm{O}$ QDAs, to optimize their catalytic activity. Our hypothesis was that using a low concentration of palladium solution during galvanic displacement would give less $\mathrm{Pd}$ and more $\mathrm{Cu}_{2} \mathrm{O}$ clusters, and vice versa. Thus, we prepared QDAs with different $\mathrm{Pd} / \mathrm{Cu}$ mass ratios $(0.2: 8,0.5: 8,1: 8,2: 8$, and $5: 8$ ) from the same $\mathrm{Cu} / \mathrm{C}$ ( 8 wt \% $\mathrm{Cu}$ loading) with varying amounts of palladium in the solution during galvanic displacement. The five catalysts are denoted using their Pd/ $\mathrm{Cu}$ percentage mass ratios in subscript before the element symbol (e.g., ${ }_{0.2} \mathrm{Pd}_{8} \mathrm{Cu} / \mathrm{C}$ refers to a QDA with 0.2 wt\% palladium and $8 \mathrm{wt} \%$ copper supported on Vulcan). Additional monometallic palladium catalysts $(\mathrm{Pd} / \mathrm{C})$ were prepared as control samples.

X-ray diffraction (XRD) was used to determine the bulk crystal phases of the $\mathrm{Pd}-\mathrm{Cu} / \mathrm{C}, \mathrm{Pd} / \mathrm{C}$, and $\mathrm{Cu} / \mathrm{C}$ catalysts.
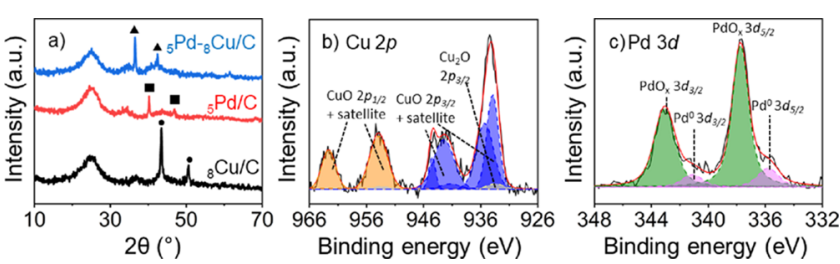

Figure 2. (a) XRD patterns of ${ }_{8} \mathrm{Cu} / \mathrm{C},{ }_{5} \mathrm{Pd} / \mathrm{C}$, and ${ }_{5} \mathrm{Pd}-{ }_{8} \mathrm{Cu} / \mathrm{C}$ with $\mathrm{Cu}$ (solid circle), $\mathrm{Cu}_{2} \mathrm{O}$ (solid triangle), and $\mathrm{Pd}$ (solid square); (b) deconvoluted $\mathrm{Cu} 2 p$ X-ray photoelectron spectroscopy (XPS) spectrum of ${ }_{5} \mathrm{Pd}{ }_{8} \mathrm{Cu} / \mathrm{C}$; (c) deconvoluted Pd $3 d$ XPS spectrum of ${ }_{5} \mathrm{Pd}{ }_{8} \mathrm{Cu} / \mathrm{C}$; the red lines are the spectral envelopes.

Figure $2 \mathrm{a}$ shows the diffraction patterns of the ${ }_{5} \mathrm{Pd}{ }_{8} \mathrm{Cu} / \mathrm{C}$, ${ }_{5} \mathrm{Pd} / \mathrm{C}$, and ${ }_{8} \mathrm{Cu} / \mathrm{C}$ catalysts (for clarity and brevity, we discuss here only the $\mathrm{XRD}$ of ${ }_{5} \mathrm{Pd}{ }_{8} \mathrm{Cu} / \mathrm{C}$; other results are shown in Figure $\mathrm{S} 1$ in the Supporting Information). The ${ }_{5} \mathrm{Pd}-{ }_{8} \mathrm{Cu}$ sample shows the characteristic peaks of $\mathrm{Cu}_{2} \mathrm{O}\left(36.6^{\circ}\right.$ (111) and $42.5^{\circ}$ (200), COD 1000063), while no Pd peaks are observed. This pertains to the formation of ultrasmall $\mathrm{Pd}$ nanoparticles, and these local structures of the catalyst were further examined using other techniques (vide infra). Only peaks for metallic copper $\left(43.5^{\circ}(111)\right.$ and $50.7^{\circ}(200)$, COD 9011604) are observed in the diffractogram of the ${ }_{8} \mathrm{Cu} / \mathrm{C}$ catalyst, showing that the cuprous oxide in the $\mathrm{Pd}-\mathrm{Cu} / \mathrm{C}$ QDAs formed during the galvanic displacement, and not by air oxidation. The control catalyst ${ }_{5} \mathrm{Pd} / \mathrm{C}$ shows peaks for metallic Pd (40.2 ${ }^{\circ}$ (111) and $46.8^{\circ}$ (200), COD 1011106).

Further insight into the surface composition was gained via XPS performed ex situ on the ${ }_{5} \mathrm{Pd}_{8} \mathrm{Cu} / \mathrm{C}$ QDA. The $\mathrm{Cu} 2 p$ and $\mathrm{Pd} 3 d$ spectra of the ${ }_{5} \mathrm{Pd}-{ }_{8} \mathrm{Cu} / \mathrm{C}$ QDA are shown in Figure $2 \mathrm{~b}$ and $\mathrm{c}$ and are used for the chemical interpretation. ${ }^{31-33}$ The $\mathrm{Cu} 2 p_{3 / 2}$ peak suggests that the sample surface is rich in $\mathrm{Cu}^{2+}$ oxide, as shown by the peak position and the characteristic strong satellite peaks. The peak at $933 \mathrm{eV}$ (gray in Figure 2b) was assigned to the $\mathrm{Cu}^{1+}$ oxide, which accounts for approximately $2.6 \%$ of the sample volume probed by XPS. The discrepancy between the XRD and XPS results is attributed to the oxygen spillover from $\mathrm{Pd}$ to $\mathrm{Cu}_{2} \mathrm{O}$ on the material surface when the catalyst is exposed to air for a long period of time. This hypothesis was supported by the Pd $3 d$ peak, showing $86 \%$ palladium oxide and $14 \%$ metallic 
palladium (Figure 2c, green and pink peaks, respectively). A palladium to copper ratio of $0.72: 1$ was determined in the ${ }_{5} \mathrm{Pd}{ }_{8} \mathrm{Cu} / \mathrm{C}$ QDA using the $\mathrm{Pd} 3 d$ and $\mathrm{Cu} 3 p$ peaks (see Figure $\mathrm{S} 2$ ). As $\mathrm{Cu} 3 p$ is closer in kinetic energy to $\mathrm{Pd} 3 d$ than $\mathrm{Cu} 2 p$, the probing depths will be similar. This ratio is comparable with the theoretical one of $0.63: 1$ based on the synthetic procedure, which is also verified by the microscopy analysis (vide infra).

Transmission electron microscopy (TEM) studies of the ${ }_{2} \mathrm{Pd}{ }_{8} \mathrm{Cu} / \mathrm{C}$ catalyst reveal that the QDAs, with the size between 10 and $25 \mathrm{~nm}$, uniformly distributed on the carbon surface (see Figure 3a). A clear view of the metallic QDAs was
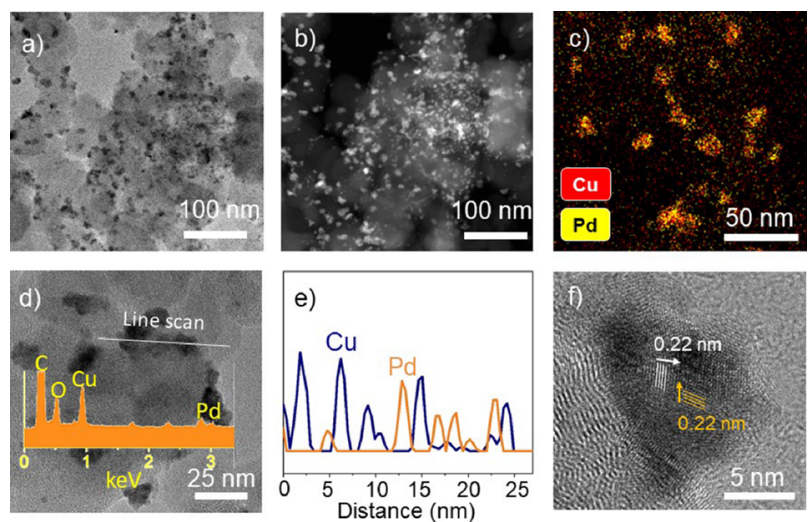

Figure 3. Microscopy characterization of ${ }_{2} \mathrm{Pd}_{8} \mathrm{Cu} / \mathrm{C}$ QDA: (a) TEM micrograph; (b) HAADF-STEM micrograph; (c) EDS elemental mapping; (d) TEM image of the QDA where the EDS line scan was performed, and the inset shows the EDS spectrum of the entire area; (e) TEM-EDS line scan analysis of $\mathrm{Cu}$ and Pd; (f) HRTEM micrograph.

obtained via high angle annular dark field-scanning transmission electron microscopy (HAADF-STEM, Figure 3b) imaging. All the QDAs contain both palladium and copper, as shown by the elemental mappings obtained using energydispersive spectroscopy (EDS, see Figure 3c). No monometallic species were observed. This confirms that Pd grows from $\mathrm{Cu}$ nanoparticles during the galvanic displacement. We also performed the EDS line scan of the QDAs at the nanoscale (Figure 3d). The scan profile in Figure 3e shows alternating signals for $\mathrm{Cu}$ and $\mathrm{Pd}$, implying the formation of the QDA structure as illustrated in Figure 1. In particular, the size of all $\mathrm{Cu}$ and $\mathrm{Pd}$ domains is less than $3 \mathrm{~nm}$, which corroborates the quantum-dot nature of both $\mathrm{Cu}_{2} \mathrm{O}$ and $\mathrm{Pd}$ particles. Since $\mathrm{Cu}$ is not in the metallic but oxide form, the direct bond formation between $\mathrm{Cu}$ and $\mathrm{Pd}$ is unlikely (see our simulation model below). We thus relied on high-resolution TEM (HRTEM) to understand the local structure and the interface of the cluster. The HRTEM micrograph shown in Figure $3 \mathrm{f}$ reveals that the particles are assemblies of multiple quantum dots, showing that $\mathrm{Pd}$ and $\mathrm{Cu}_{2} \mathrm{O}$ are strongly bound at the interface. The interplanar spacings in these nanoclusters are $\sim 0.22 \mathrm{~nm}$, corresponding to either $\mathrm{Pd}(111)$ or $\mathrm{Cu}_{2} \mathrm{O}$ (200) with a small lattice expansion. . $^{4,35}$

2.2. Catalytic Performance of QDAs and Mechanistic Studies. To examine the catalytic performance of the new structure, we used the $\mathrm{Pd}-\mathrm{Cu} / \mathrm{C}$ QDAs in three electrooxidation examples: formaldehyde, glucose, and ethanol. These oxidations are important in a number of practical applications, such as in fuel cells, (bio)sensing, and wastewater treatment. ${ }^{36}$
The conversion of formaldehyde is also relevant in the ECD process. For the formaldehyde oxidation reaction, we used a classical 3-electrode setup with an alkaline electrolyte containing $\mathrm{KOH}$, ethylenediaminetetraacetic acid (EDTA), and formaldehyde. EDTA was added to simulate the environment of the ECD process (it is commonly added to ensure the stability of $\mathrm{Cu}^{2+}$ and the quality of the deposited layer). The $\mathrm{Pd} / \mathrm{C}$ catalyst was tested in both the blank bath (formaldehyde-free) and formaldehyde bath (see Figure 4a;
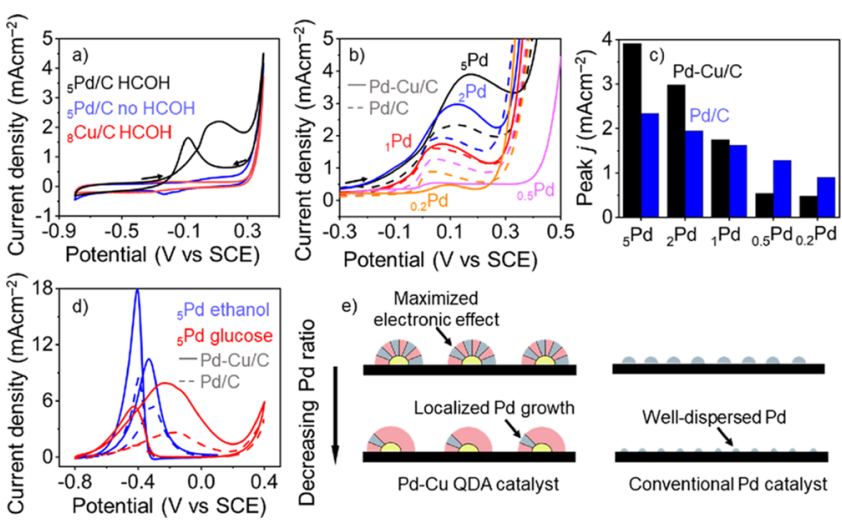

Figure 4. (a) $\mathrm{CV}$ curves of ${ }_{5} \mathrm{Pd} / \mathrm{C}$ and ${ }_{8} \mathrm{Cu} / \mathrm{C}$ in $\mathrm{HCOH}$-free and $\mathrm{HCOH}$ bath; (b) comparison of linear sweep voltammetry (LSV) curves of Pd-Cu/C QDAs (solid lines) with the corresponding Pd/C (dashed lines) with the same Pd content in formaldehyde oxidation; (c) comparison of peak current density of different catalysts in formaldehyde oxidation; (d) $\mathrm{CV}$ curves of ${ }_{5} \mathrm{Pd} / \mathrm{C}$ and ${ }_{5} \mathrm{Pd}{ }_{8} \mathrm{Cu} / \mathrm{C}$ for both glucose and ethanol oxidation; (e) schematic structural comparison of QDA with the conventional Pd catalyst with varying Pd ratios. Test conditions are specified in the Supporting Information.

the bath compositions are given in the Supporting Information). No parasitic current from EDTA oxidation was observed in our potential range in the blank bath. The cyclic voltammetry $(\mathrm{CV})$ curve in the formaldehyde bath shows an anodic peak in the forward scan at $0.1 \mathrm{~V}$ versus the saturated calomel electrode (SCE), which is attributed to the oxidation of formaldehyde. The peak at $-0.1 \mathrm{~V}$ in the backward scan originates from the oxidation of organic fragments, which is also documented in the electro-oxidation of other small organics. ${ }^{37}$ These peaks were not observed in the experiments in the blank bath. In contrast, when the $\mathrm{Cu} / \mathrm{C}$ catalyst was tested, neither of these anodic peaks were observed. This inactivity was due to the surface oxidation of the $\mathrm{Cu}$ nanoparticles. To ensure that the reaction was carried out at the optimum temperature, we performed the $\mathrm{CV}$ at different temperatures. The highest oxidation current was observed at $45^{\circ} \mathrm{C}$ as shown in Figure S3. This temperature was used in all subsequent experiments.

We then analyzed the catalytic performance of $\mathrm{Pd}-\mathrm{Cu}_{2} \mathrm{O}$ QDAs with varying $\mathrm{Pd} / \mathrm{Cu}$ mass ratios. Comparing with the corresponding monometallic Pd/C controls, the QDAs containing $>1$ wt $\% \mathrm{Pd}$ loadings showed improved activity in the LSV curves. For example, the ${ }_{5} \mathrm{Pd}{ }_{8} \mathrm{Cu} / \mathrm{C}$ QDA had a peak oxidation current density of $3.91 \mathrm{~mA} \mathrm{~cm}^{-2}$, whereas that for ${ }_{5} \mathrm{Pd} / \mathrm{C}$ was $2.34 \mathrm{~mA} \mathrm{~cm}^{-2}$ (see Figure $4 \mathrm{~b}$ and $\mathrm{c}$ ). The structural advantage of $\mathrm{Pd}-\mathrm{Cu}_{2} \mathrm{O}$ QDAs was also valid in the glucose electro-oxidation performed in a $0.5 \mathrm{M} \mathrm{KOH}+0.5 \mathrm{M}$ glucose electrolyte. Two peaks are observed in the CV curve (Figure $4 \mathrm{~d}$, scan rate $50 \mathrm{mVs}^{-1}$ ): a peak in the forward scan at $-0.23 \mathrm{~V}$ 
versus the SCE and the other one in the backward scan at $-0.43 \mathrm{~V}$ versus the SCE. The former is attributed to the oxidation of glucose, while the latter is attributed to the oxidation of bound intermediates, which are not oxidized during the forward scan. ${ }^{38}$ The peaks have a small positive shift (0.04 and $0.03 \mathrm{~V}$ for the forward and backward scan, respectively) for ${ }_{5} \mathrm{Pd} / \mathrm{C}$. The peak current density for glucose oxidation of ${ }_{5} \mathrm{Pd}-{ }_{8} \mathrm{Cu} / \mathrm{C}$ is $\sim 3$ times higher than that of ${ }_{5} \mathrm{Pd} / \mathrm{C}$ $\left(7.90 \mathrm{mAcm}^{-2}, 17.6 \mathrm{Acm}^{-2} \mathrm{mg}_{\mathrm{Pd}}{ }^{-1}\right.$ vs $2.67 \mathrm{mAcm}^{-2}, 5.93$ $\left.\mathrm{Acm}^{-2} \mathrm{mg}_{\mathrm{Pd}}{ }^{-1}\right)$. A similar result was obtained in the ethanol oxidation reaction performed in $1.0 \mathrm{M}$ ethanol and $1.0 \mathrm{M}$ $\mathrm{KOH}$ electrolyte. The superior performance of QDA in the oxidation of these small organic molecules emphasizes the importance of the interaction between the $\mathrm{Pd}$ and $\mathrm{Cu}_{2} \mathrm{O}$ domains.

We hypothesize that the catalytic advantages of QDAs come from the maximized interfacial electronic effect between $\mathrm{Pd}$ and $\mathrm{Cu}_{2} \mathrm{O}$ quantum dots (see the illustration in Figure 1). Such an effect is prominent only when the size of $\mathrm{Pd}$ and $\mathrm{Cu}_{2} \mathrm{O}$ dots is the same, maximizing the phase boundaries. When the Pd ratio decreases, this effect diminishes accordingly and the QDA will perform similar to pure Pd (1 wt \% Pd). However, at extremely low Pd loadings (e.g., 0.5 and 0.2 wt \% Pd, see Figure 4d), the low $\mathrm{Pd}^{2+}$ cation concentration in the galvanic displacement bath results in the formation of much less $\mathrm{Pd}$ nuclei, which subsequently undergo nonepitaxial and continuous growth. Therefore, nonuniformly dispersed, localized and large $\mathrm{Pd}$ dots are observed on the $\mathrm{Cu}$ particles (see Figure $4 \mathrm{e})$. Hence, these QDAs perform worse than the corresponding $\mathrm{Pd} / \mathrm{C}$ with well-distributed $\mathrm{Pd}$ nanoparticles.

To understand and verify the interfacial properties, we have constructed a $\mathrm{Pd}-\mathrm{Cu}_{2} \mathrm{O}$ QDA model and performed density functional theory (DFT) calculations. Figure 5a shows the

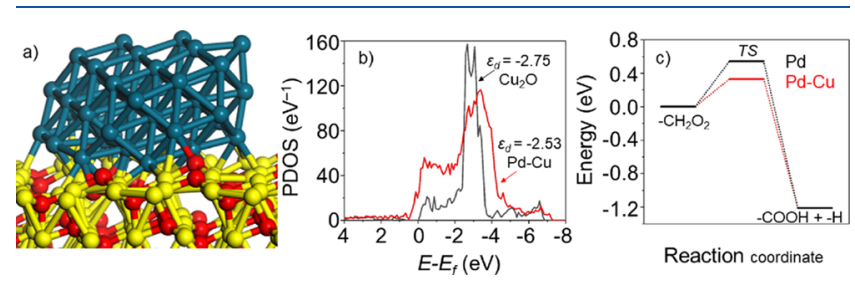

Figure 5. (a) Configuration of the $\mathrm{Pd}-\mathrm{Cu}_{2} \mathrm{O}$ QDA model; (b) PDOS for $\mathrm{Cu}_{2} \mathrm{O}$ and $\mathrm{Pd}-\mathrm{Cu}_{2} \mathrm{O}$ QDA; (c) DFT energy diagram of $-\mathrm{CH}_{2} \mathrm{O}_{2}$ conversion on $\mathrm{Pd}$ and $\mathrm{Pd}-\mathrm{Cu}_{2} \mathrm{O}$ QDA with normalized zero potential energy.

optimized heterostructure containing a 46-atom Pd cluster on the $\mathrm{Cu}_{2} \mathrm{O}$ (111) surface. This structure is thermodynamically favorable, as the interface has more interfacial bonds and less strain stress. ${ }^{39}$ Because of the formation of the interfacial Pd$\mathrm{O}$ and $\mathrm{Pd}-\mathrm{Cu}$ bonds, charge accumulation at the boundary is observed. This has substantially changed the projected density of states (PDOS) in the interface (see Figure 5b). The d-band center $\left(\varepsilon_{\mathrm{d}}\right)$ of the QDA was upshifted to $-2.53 \mathrm{eV}$ toward the Fermi level compared to $-2.75 \mathrm{eV}$ of $\mathrm{Cu}_{2} \mathrm{O}$. The catalytic benefits of the optimized electronic structure are shown in the potential energy diagram, Figure $5 \mathrm{c}$. We used the optimized Meerakker's model ${ }^{40}$ in alkaline media in which $\mathrm{HCHO}$ is in equilibrium with $\mathrm{CH}_{2} \mathrm{OOH}^{-}$:

$$
\begin{aligned}
& \mathrm{HCHO}+\mathrm{H}_{2} \mathrm{O} \leftrightarrow \mathrm{CH}_{2}(\mathrm{OH})_{2} \\
& \mathrm{CH}_{2}(\mathrm{OH})_{2}+\mathrm{OH}^{-} \leftrightarrow \mathrm{CH}_{2} \mathrm{OOH}^{-}+\mathrm{H}_{2} \mathrm{O}
\end{aligned}
$$

The elementary reactions are as follows:

$$
\begin{aligned}
& -\mathrm{CH}_{2} \mathrm{OOH}^{-}+\mathrm{OH}^{-} \rightarrow-\mathrm{CH}_{2} \mathrm{O}_{2}{ }^{2-}+\mathrm{H}_{2} \mathrm{O} \\
& -\mathrm{CH}_{2} \mathrm{O}_{2}{ }^{2-}+-* \rightarrow-\mathrm{COOH}^{-}+-\mathrm{H}+e^{-} \\
& -\mathrm{H}+\mathrm{OH}^{-} \rightarrow \mathrm{H}_{2} \mathrm{O}+e^{-}
\end{aligned}
$$

where eq 8 is the rate-determining step. The calculation indicates that the activation energy barrier from $\mathrm{CH}_{2} \mathrm{O}_{2}$ to $\mathrm{COOH}$ decreased by $0.21 \mathrm{eV}$ when the catalytic surface is switched from $\mathrm{Pd}$ to the $\mathrm{Pd}-\mathrm{Cu}_{2} \mathrm{O}$ QDA model.

2.3. Industrial Application in Electroless Deposition. We then tested the performance of the $\mathrm{Pd}-\mathrm{Cu}_{2} \mathrm{O}$ QDAs in ECD. This industrially relevant technique plates a surface with a copper layer for anticorrosion applications or PCB manufacturing. ${ }^{41,42}$ The plating is performed in a bath containing metal ions and a reducing agent (eq 10). Although this reaction is autocatalytic, it must be initiated by a catalyst. The state-of-the-art Pd initiator is rather expensive, and replacing it with cheaper and more active materials is industrially important.

$$
\mathrm{M}^{x+}+\operatorname{Red}^{n} \rightarrow \mathrm{M}^{0}+\operatorname{Red}^{n+x}
$$

In the traditional alkaline formaldehyde bath, the reduction of EDTA-stabilized $\mathrm{Cu}^{2+}$ cations proceeds through the adsorption of formaldehyde hydrate on the catalyst surface followed by anodic oxidation to formate (eq 11). ${ }^{29}$ The electrons liberated from this process are transferred for cathodic $\mathrm{Cu}$ deposition (eq 12). The combination of both reactions gives the overall cell reaction (eq 13). The initiator catalyzes this reaction via facilitating the oxidation of formaldehyde.

$$
\begin{aligned}
& \mathrm{HCOO}^{-}+2 \mathrm{H}_{2} \mathrm{O}+2 \mathrm{e}^{-} \rightarrow \mathrm{HCOH}+3 \mathrm{OH}^{-} \\
& (\mathrm{pH}=14) \quad \mathrm{E}=-1.070 \mathrm{~V} \\
& {[\mathrm{CuEDTA}]^{2-}+2 \mathrm{e}^{-} \rightarrow \mathrm{Cu}^{0}+\mathrm{EDTA}^{4-}} \\
& \mathrm{E}=-0.216 \mathrm{~V} \\
& \mathrm{HCOH}+3 \mathrm{OH}^{-}+\mathrm{Cu}^{2+} \rightarrow \mathrm{HCOO}^{-}+2 \mathrm{H}_{2} \mathrm{O}+\mathrm{Cu}^{0} \\
& (\mathrm{pH}=14) \quad E=+0.854 \mathrm{~V}
\end{aligned}
$$

We have shown that the $\mathrm{Pd}-\mathrm{Cu}_{2} \mathrm{O}$ QDAs are excellent catalysts for formaldehyde oxidation (vide supra). Yet, monitoring both the formaldehyde oxidation and copper reduction gives a much clearer picture. Thus, we first used the mixed potential theory to further analyze the activity of both ${ }_{5} \mathrm{Pd} / \mathrm{C}$ and ${ }_{5} \mathrm{Pd}-{ }_{8} \mathrm{Cu} / \mathrm{C}$ QDA catalysts in ECD. The mixed potential theory concludes that the maximum electrochemical reaction rate is achieved when both the anodic and cathodic reactions occur at the same rate, resulting in no buildup of electrons at the interface. The kinetics can be derived from the intersection between the two half-reaction Tafel curves. Here, we measured the Tafel curves for copper reduction and formaldehyde oxidation for both the ${ }_{5} \mathrm{Pd} / \mathrm{C}$ catalyst and ${ }_{5} \mathrm{Pd}-{ }_{8} \mathrm{Cu} / \mathrm{C}$ QDA (Figure 6a,b). For ${ }_{5} \mathrm{Pd} / \mathrm{C}$, the curves intersect at $-0.41 \mathrm{~V}$ vs SCE with a current density of 0.28 $\mathrm{mAcm}^{-2}$. In contrast, the ${ }_{5} \mathrm{Pd}-{ }_{8} \mathrm{Cu} / \mathrm{C}$ QDA intersects at a lower potential $(-0.52 \mathrm{~V}$ vs SCE), while showing a substantially increased current density of $0.53 \mathrm{mAcm}^{-2}$. We hence conclude that the ${ }_{5} \mathrm{Pd}_{8} \mathrm{Cu} / \mathrm{C}$ QDA also outperformed the monometallic ${ }_{5} \mathrm{Pd} / \mathrm{C}$ catalyst in the ECD. 

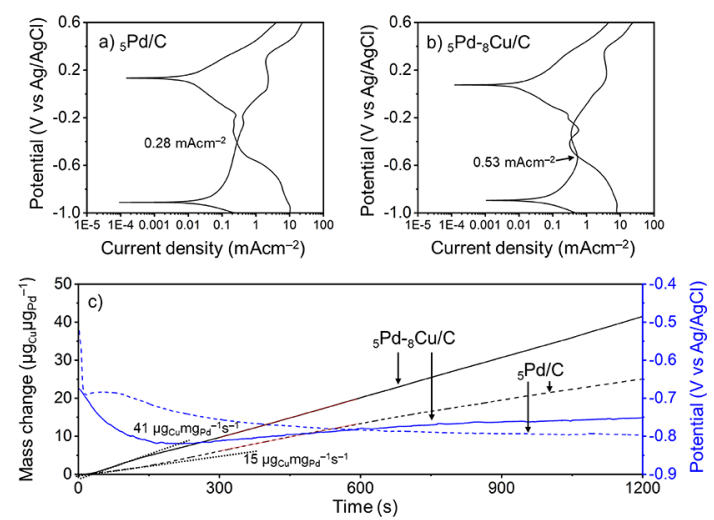

Figure 6. Tafel curves recorded in their respective baths for formaldehyde oxidation and copper reduction for $(\mathrm{a}){ }_{5} \mathrm{Pd} / \mathrm{C}$ and (b) ${ }_{5} \mathrm{Pd}-{ }_{8} \mathrm{Cu} / \mathrm{C}$; (c) mass change and potential during $\mathrm{ECD}$ measured via eQCM of ${ }_{5} \mathrm{Pd}-{ }_{8} \mathrm{Cu} / \mathrm{C}$ (solid lines) and ${ }_{5} \mathrm{Pd} / \mathrm{C}$ (dashed lines). For conditions and bath compositions, see the Supporting Information.

As the mixed potential theory only gives an indication of the initial activity of the catalyst, we also used an electrochemical quartz crystal microbalance (eQCM) to monitor both the deposition rate and surface potential. The quartz crystals were coated with the catalysts and then subjected to the ECD bath (see Table S2 for both compositions). During ECD, the frequency variations of this crystal were monitored, which are correlated to the mass change. Simultaneously, the potential was also recorded, revealing more information about the electrochemical nature of the plating process. Both the ${ }_{5} \mathrm{Pd}{ }_{8} \mathrm{Cu} / \mathrm{C}$ QDA and ${ }_{5} \mathrm{Pd} / \mathrm{C}$ catalysts were examined in this eQCM system. A plot of the potential and mass change versus time is shown in Figure 6c. Deposition rates of 35 and $21 \mu \mathrm{g}_{\mathrm{Cu}}$ $\mathrm{mg}_{\mathrm{Pd}}{ }^{-1} \mathrm{~s}^{-1}$ are derived from the total plating time for ${ }_{5} \mathrm{Pd}-{ }_{8} \mathrm{Cu} /$ $\mathrm{C}$ and ${ }_{5} \mathrm{Pd} / \mathrm{C}$, respectively (deposition rates are denoted as the amount of plated copper per mg of palladium per second). For both catalysts, a linear increase for the mass change is observed after the first $150 \mathrm{~s}$. This linearity comes from the uniformly plated copper on the surface, which autocatalytically grows at a constant rate. The differences in the deposition rate for 150$1200 \mathrm{~s}$ period come from the surface area differences of the predeposited copper film.

We thus obtained the plating kinetics of the ${ }_{5} \mathrm{Pd}-{ }_{8} \mathrm{Cu} / \mathrm{C}$ and ${ }_{5} \mathrm{Pd} / \mathrm{C}$ catalysts from the first $150 \mathrm{~s}$ of ECD. The first $15 \mathrm{~s}$ is an induction period in which the system equilibrates to the plating bath. After this period, the ${ }_{5} \mathrm{Pd}-{ }_{-} \mathrm{Cu} / \mathrm{C}$ QDA achieved a deposition rate of $41 \mu \mathrm{g}_{\mathrm{Cu}} \mathrm{mg}_{\mathrm{Pd}}{ }^{-1} \mathrm{~s}^{-1}$. This is faster than that of the monometallic ${ }_{5} \mathrm{Pd} / \mathrm{C}$ catalyst, which had a deposition rate of $15 \mu \mathrm{g}_{\mathrm{Cu}} \mathrm{mg}_{\mathrm{Pd}}{ }^{-1} \mathrm{~s}^{-1}$. Furthermore, the initial deposition rate of ${ }_{5} \mathrm{Pd}-{ }_{8} \mathrm{Cu} / \mathrm{C}$ is faster than that during autocatalysis, which is catalyzed by the deposited $\mathrm{Cu}$ layer, whereas this rate for ${ }_{5} \mathrm{Pd} /$ $\mathrm{C}$ is lower than that during the autocatalysis. This implies that the activity order is ${ }_{5} \mathrm{Pd}-{ }_{8} \mathrm{Cu} / \mathrm{C}$ QDA $>\mathrm{Cu}>{ }_{5} \mathrm{Pd} / \mathrm{C}$. This trend is also reflected by the potential profiles of the two materials. From the autocatalysis region in Figure $6 c$, we found the potential for autocatalyzed ECD is in the range of -0.75 to $-0.8 \mathrm{~V}$ versus $\mathrm{Ag} / \mathrm{AgCl}$. After the initial induction period, the potential of the ${ }_{5} \mathrm{Pd}-{ }_{8} \mathrm{Cu} / \mathrm{C}$ QDA became lower than the autocatalytic ECD potential, whereas that of ${ }_{5} \mathrm{Pd} / \mathrm{C}$ remained higher than the autocatalytic potential.

We finally demonstrate the excellent mechanical and electronic properties of the $\mathrm{Cu}$ deposit layer initiated by the ${ }_{5} \mathrm{Pd}-{ }_{8} \mathrm{Cu} / \mathrm{C}$ QDA by plating copper wires on a flexible silicon rubber substrate. The QDA catalyst was airbrushed onto the substrate using a simple mask with the logo of the University of Amsterdam. After ECD, the copper layer was uniformly and exclusively deposited within the pattern where catalyst was spray-painted (Figure 7a). The copper pattern is highly

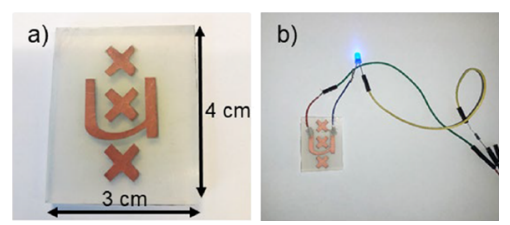

Figure 7. (a) The University of Amsterdam logo plated on a silicon rubber plate; (b) conductivity test of the plated surface using a LED assembly.

conductive and could be used as wires to successfully power a light-emitting diode (LED) assembly (Figure 7b). This shows the potential of using the new catalyst in the context of industrial applications.

\section{CONCLUSIONS}

We developed a novel QDA catalyst via a galvanic displacement approach, consisting of $3 \mathrm{~nm} \mathrm{Cu}_{2} \mathrm{O}$ and $\mathrm{Pd}$ clusters. These QDAs are better electrocatalysts for the oxidation of formaldehyde, glucose, and ethanol, outperforming equivalent monometallic catalysts. Together with the DFT simulations, we conclude that the activity enhancement originated from the maximized interfacial electronic effect between $\mathrm{Pd}$ and $\mathrm{Cu}_{2} \mathrm{O}$ quantum dots. The industrial relevance of the new catalyst was demonstrated by the excellent performance in initiating the $\mathrm{ECD}$, yet reducing the $\mathrm{Pd}-\mathrm{Cu}_{2} \mathrm{O}$ metal loading in the future will make the supported catalyst even more promising for industrial processes. We believe that this catalyst structure opens opportunities for designing better catalytic materials at the ultrasmall nanoscale.

\section{ASSOCIATED CONTENT}

\section{SI Supporting Information}

The Supporting Information is available free of charge at https://pubs.acs.org/doi/10.1021/acsanm.0c02162.

Protocols of materials synthesis, electrochemical test, and materials characterizations; additional XRD, XPS, and electrochemical results (PDF)

\section{AUTHOR INFORMATION}

\section{Corresponding Author}

Ning Yan - Van't Hoff Institute for Molecular Sciences (HIMS), University of Amsterdam, 1098XH Amsterdam, The Netherlands; (1) orcid.org/0000-0001-6677-7507; Email: n.yan@uva.nl

\section{Authors}

Jasper Biemolt - Van't Hoff Institute for Molecular Sciences (HIMS), University of Amsterdam, 1098XH Amsterdam, The Netherlands; 이이이.org/0000-0001-8566-4989

Dylan van Noordenne - Van't Hoff Institute for Molecular Sciences (HIMS), University of Amsterdam, 1098XH Amsterdam, The Netherlands

Jianwen Liu - College of Materials Science and Engineering, Shenzhen University, Shenzhen 518055, China; O orcid.org/ 0000-0003-2395-6913 
Elise Antonetti - Van't Hoff Institute for Molecular Sciences (HIMS), University of Amsterdam, 1098XH Amsterdam, The Netherlands

Manon Leconte - Van't Hoff Institute for Molecular Sciences (HIMS), University of Amsterdam, 1098XH Amsterdam, The Netherlands

Stefan van Vliet - Advanced Research Center for Nanolithography, 1098XG Amsterdam, the Netherlands

Roland Bliem - Advanced Research Center for Nanolithography, 1098XG Amsterdam, the Netherlands; (1) orcid.org/0000-0002-8714-8942

Gadi Rothenberg - Van't Hoff Institute for Molecular Sciences (HIMS), University of Amsterdam, 1098XH Amsterdam, The Netherlands

Xian-Zhu Fu - College of Materials Science and Engineering, Shenzhen University, Shenzhen 518055, China; (1) orcid.org/ 0000-0003-1843-8927

Complete contact information is available at:

https://pubs.acs.org/10.1021/acsanm.0c02162

\section{Notes}

The authors declare no competing financial interest.

\section{ACKNOWLEDGMENTS}

We are thankful for the financial support from the Netherlands Organization for Scientific Research (NWO) NWO-GDST Advanced Materials program (project No. 729.001.022). This work is part of the Research Priority Area Sustainable Chemistry of the UvA, http://suschem.uva.nl.

\section{REFERENCES}

(1) Chen, C.; Nan, C.; Wang, D.; Su, Q.; Duan, H.; Liu, X.; Zhang, L.; Chu, D.; Song, W.; Peng, Q.; Li, Y. Mesoporous Multicomponent Nanocomposite Colloidal Spheres: Ideal High-Temperature Stable Model Catalysts. Angew. Chem., Int. Ed. 2011, 50, 3725-3729.

(2) Liu, L.; Jiao, J.; Wei, W.; Lv, B.; Liu, Y.; Hu, Z.; Tang, J. Construction of Multicomponent Nanocomposite $\mathrm{CdSe} / \mathrm{NaY}-$ $\mathrm{F}_{4}: \mathrm{Yb}$,Er Colloidal Spheres for Tuning Visible Light. Scr. Mater. 2019, 169, 61-64.

(3) Liu, J.; Wang, J.; Zhang, B.; Ruan, Y.; Wan, H.; Ji, X.; Xu, K.; Zha, D.; Miao, L.; Jiang, J. Mutually Beneficial $\mathrm{Co}_{3} \mathrm{O}_{4} @ \mathrm{MoS}_{2}$ Heterostructures as a Highly Efficient Bifunctional Catalyst for Electrochemical Overall Water Splitting. J. Mater. Chem. A 2018, 6, 2067-2072.

(4) Jiang, L.; Zhu, W.; Wang, C.; Dong, W.; Zhang, L.; Wang, G.; Chen, B.; Li, C.; Zhang, X. Preparation of Hollow Ag/Pt Heterostructures on $\mathrm{TiO}_{2}$ Nanowires and Their Catalytic Properties. Appl. Catal. B Environ. 2016, 180, 344-350.

(5) Yan, X.; Yang, Y.; Zeng, Y.; Shalchi Amirkhiz, B.; Luo, J.-L.; Yan, N. Generating C4 Alkenes in Solid Oxide Fuel Cells via Cofeeding $\mathrm{H}_{2}$ and $n$-Butane Using a Selective Anode Electrocatalyst. ACS Appl. Mater. Interfaces 2020, 12, 16209-16215.

(6) Su, S.; Shi, Y.; Zhou, Y.; Wang, Y.-B.; Wang, F.-B.; Xia, X.-H. Tailoring the Electron Density of Pd Nanoparticles through Electronic Metal-Support Interaction for Accelerating Electrocatalysis of Formic Acid. Electrochem. Commun. 2019, 107, 106540.

(7) Kang, Y.; Ye, X.; Chen, J.; Cai, Y.; Diaz, R. E.; Adzic, R. R.; Stach, E. A.; Murray, C. B. Design of Pt-Pd Binary Superlattices Exploiting Shape Effects and Synergistic Effects for Oxygen Reduction Reactions. J. Am. Chem. Soc. 2013, 135, 42-45.

(8) Yan, N.; Pandey, J.; Zeng, Y.; Amirkhiz, B. S.; Hua, B.; Geels, N. J.; Luo, J.-L.; Rothenberg, G. Developing a Thermal- and CokingResistant Cobalt-Tungsten Bimetallic Anode Catalyst for Solid Oxide Fuel Cells. ACS Catal. 2016, 6, 4630-4634.
(9) Wang, X.; Sun, G.; Li, N.; Chen, P. Quantum Dots Derived from Two-Dimensional Materials and Their Applications for Catalysis and Energy. Chem. Soc. Rev. 2016, 45, 2239-2262.

(10) Li, H.; Li, L.; Li, Y. The Electronic Structure and Geometric Structure of Nanoclusters as Catalytic Active Sites. Nanotechnol. Rev. 2013, 2, 515-528.

(11) Zhou, X.; Tian, Z.; Li, J.; Ruan, H.; Ma, Y.; Yang, Z.; Qu, Y. Synergistically Enhanced Activity of Graphene Quantum Dot/MultiWalled Carbon Nanotube Composites as Metal-Free Catalysts for Oxygen Reduction Reaction. Nanoscale 2014, 6, 2603.

(12) Roduner, E. Size Matters: Why Nanomaterials Are Different. Chem. Soc. Rev. 2006, 35, 583.

(13) Wang, H.; Gu, X.-K.; Zheng, X.; Pan, H.; Zhu, J.; Chen, S.; Cao, L.; Li, W.-X.; Lu, J. Disentangling the Size-Dependent Geometric and Electronic Effects of Palladium Nanocatalysts beyond Selectivity. Sci. Adv. 2019, 5, No. eaat6413.

(14) LaMer, V. K.; Dinegar, R. H. Theory, Production and Mechanism of Formation of Monodispersed Hydrosols. J. Am. Chem. Soc. 1950, 72, 4847-4854.

(15) Sun, Y. Controlled Synthesis of Colloidal Silver Nanoparticles in Organic Solutions: Empirical Rules for Nucleation Engineering. Chem. Soc. Rev. 2013, 42, 2497-2511.

(16) Lee, C.-L.; Syu, C.-C.; Chiou, H.-P.; Liu, C.-R.; Huang, C.-H. Effect of Electrochemical Surface Area on Electroless Copper Deposition: Pd Nanocubes as New Activators. Electrochim. Acta 2012, 59, 587-591.

(17) Chiu, C.-Y.; Chung, P.-J.; Lao, K.-U.; Liao, C.-W.; Huang, M. H. Facet-Dependent Catalytic Activity of Gold Nanocubes, Octahedra, and Rhombic Dodecahedra toward 4-Nitroaniline Reduction. J. Phys. Chem. C 2012, 116, 23757-23763.

(18) McEachran, M.; Keogh, D.; Pietrobon, B.; Cathcart, N.; Gourevich, I.; Coombs, N.; Kitaev, V. Ultrathin Gold Nanoframes through Surfactant-Free Templating of Faceted Pentagonal Silver Nanoparticles. J. Am. Chem. Soc. 2011, 133, 8066-8069.

(19) George, S. M. Atomic Layer Deposition: An Overview. Chem. Rev. 2010, 110, 111-131.

(20) Johnson, R. W.; Hultqvist, A.; Bent, S. F. A Brief Review of Atomic Layer Deposition: From Fundamentals to Applications. Mater. Today 2014, 17, 236-246.

(21) Lu, J.; Fu, B.; Kung, M. C.; Xiao, G.; Elam, J. W.; Kung, H. H.; Stair, P. C. Coking- and Sintering-Resistant Palladium Catalysts Achieved Through Atomic Layer Deposition. Science 2012, 335, 1205-1208.

(22) Liu, R.; Lin, Y.; Chou, L.-Y.; Sheehan, S. W.; He, W.; Zhang, F.; Hou, H. J. M.; Wang, D. Water Splitting by Tungsten Oxide Prepared by Atomic Layer Deposition and Decorated with an Oxygen-Evolving Catalyst. Angew. Chem., Int. Ed. 2011, 50, 499-502.

(23) Ge, H.; Zhang, B.; Gu, X.; Liang, H.; Yang, H.; Gao, Z.; Wang, J.; Qin, Y. A Tandem Catalyst with Multiple Metal Oxide Interfaces Produced by Atomic Layer Deposition. Angew. Chem., Int. Ed. 2016, 55, 7081-7085.

(24) Papaderakis, A.; Mintsouli, I.; Georgieva, J.; Sotiropoulos, S. Electrocatalysts Prepared by Galvanic Replacement. Catalysts 2017, 7, 80.

(25) Alia, S. M.; Yan, Y. S.; Pivovar, B. S. Galvanic Displacement as a Route to Highly Active and Durable Extended Surface Electrocatalysts. Catal. Sci. Technol. 2014, 4, 3589-3600.

(26) Hangarter, C. M.; Lee, Y.-I.; Hernandez, S. C.; Choa, Y.; Myung, N. V. Nanopeapods by Galvanic Displacement Reaction. Angew. Chem., Int. Ed. 2010, 49, 7081-7085.

(27) Strand, M. B.; Leong, G. J.; Tassone, C. J.; Larsen, B.; Neyerlin, K. C.; Gorman, B.; Diercks, D. R.; Pylypenko, S.; Pivovar, B.; Richards, R. M. Mechanistic Study of Shape-Anisotropic Nanomaterials Synthesized via Spontaneous Galvanic Displacement. J. Phys. Chem. C 2016, 120, 25053-25060.

(28) Shacham-Diamand, Y.; Osaka, T.; Okinaka, Y.; Sugiyama, A.; Dubin, V. 30years of Electroless Plating for Semiconductor and Polymer Micro-Systems. Microelectron. Eng. 2015, 132, 35-45. 
(29) Ghosh, S. Electroless Copper Deposition: A Critical Review. Thin Solid Films 2019, 669, 641-658.

(30) Haynes, W. M. CRC Handbook of Chemistry and Physics, 93rd Edition; CRC Press, 2012.

(31) Biesinger, M. C. Advanced Analysis of Copper X-Ray Photoelectron Spectra: Advanced Analysis of Copper X-Ray Photoelectron Spectra. Surf. Interface Anal. 2017, 49, 1325-1334.

(32) Brun, M.; Berthet, A.; Bertolini, J. C. XPS, AES and Auger Parameter of Pd and PdO. J. Electron Spectrosc. Relat. Phenom. 1999, 104, 55-60.

(33) Zemlyanov, D.; Aszalos-Kiss, B.; Kleimenov, E.; Teschner, D.; Zafeiratos, S.; Hävecker, M.; Knop-Gericke, A.; Schlögl, R.; Gabasch, H.; Unterberger, W.; Hayek, K.; Klötzer, B. In Situ XPS Study of $\mathrm{Pd}(111)$ Oxidation. Part 1: $2 \mathrm{D}$ Oxide Formation in $10^{-3} \mathrm{mbar}_{2}$. Surf. Sci. 2006, 600, 983-994.

(34) Zhang, D.; Jin, C.; Tian, H.; Xiong, Y.; Zhang, H.; Qiao, P.; Fan, J.; Zhang, Z.; Li, Z. Y.; Li, J. An In Situ TEM Study of the Surface Oxidation of Palladium Nanocrystals Assisted by Electron Irradiation. Nanoscale 2017, 9, 6327-6333.

(35) Liu, P.; Li, Z.; Cai, W.; Fang, M.; Luo, X. Fabrication of Cuprous Oxide Nanoparticles by Laser Ablation in PVP Aqueous Solution. RSC Adv. 2011, 1, 847-851.

(36) Biemolt, J.; van der Veen, K.; Geels, N. J.; Rothenberg, G.; Yan, N. Efficient Oxygen Reduction to $\mathrm{H}_{2} \mathrm{O}_{2}$ in Highly Porous Manganese and Nitrogen Co-Doped Carbon Nanorods Enabling ElectroDegradation of Bulk Organics. Carbon 2019, 155, 643-649.

(37) Kaedi, F.; Yavari, Z.; Asmaei, M.; Abbasian, A. R.; Noroozifar, M. Ethanol Electrooxidation on High-Performance Mesoporous $\mathrm{ZnFe}_{2} \mathrm{O}_{4}$-Supported Palladium Nanoparticles. New J. Chem. 2019, 43, 3884-3890.

(38) Tao, B.; Miao, F.; Chu, P. K. Preparation and Characterization of a Novel Nickel-Palladium Electrode Supported by Silicon Nanowires for Direct Glucose Fuel Cell. Electrochim. Acta 2012, 65, $149-152$.

(39) Guo, Y.; Liu, J.; Xu, Y.-T.; Zhao, B.; Wang, X.; Fu, X.-Z.; Sun, R.; Wong, C.-P. In Situ Redox Growth of Mesoporous $\mathrm{Pd}-\mathrm{Cu}_{2} \mathrm{O}$ Nanoheterostructures for Improved Glucose Oxidation Electrocatalysis. Sci. Bull. 2019, 64, 764-773.

(40) Van Den Meerakker, J. On the Mechanism of Electroless Plating. II. One Mechanism for Different Reductants. J. Appl. Electrochem. 1981, 11, 395-400.

(41) Lu, Y.; Xue, L.; Li, F. Silver Nanoparticle Catalyst for Electroless Ni Deposition and the Promotion of Its Adsorption onto PET Substrate. Surf. Coat. Technol. 2010, 205, 519-524.

(42) Deckert, C. A.; Couble, E. C.; Bonetti, W. F. Through-Hole Plating. US4515829A, May 7, 1985. 